\title{
Ilmenite for pigment and metal production
}

\section{Fathi Habashi*}

Department of Mining, Metallurgical, and Materials Engineering Laval University, Quebec City, Canada

\begin{abstract}
Low-grade ilmenite can be leached with concentrated $\mathrm{HCl}$ at atmospheric pressure and at $80^{\circ} \mathrm{C}$. After filtration to separate insoluble matter the solution containing $\mathrm{TiO}^{2+}$ and $\mathrm{Fe}^{2+}$ is heated to precipitate titanium hydroxide and recover $\mathrm{HCl}$. The titanium hydroxide is then calcined to synthetic rutile containing $95+\% \mathrm{TiO}{ }_{2}$ while $\mathrm{FeCl}_{2}$ is subjected to oxyhydrolysis or fluidized be to recover $\mathrm{HCl}$ and $\mathrm{Fe}_{2} \mathrm{O}_{3}$. The process naturally can be applied to high grade ilmenite. It bypasses electric furnace process which applies only to high grade ilmenite and is superior to the sulfuric acid process which is highly pollutant. The product of this process can be used to prepare the white pigment as well as titanium metal.
\end{abstract}

\section{Introduction}

The major titanium minerals are rutile, $\mathrm{TiO}_{2}$ and ilmenite, $\mathrm{FeTiO}_{3}$ (Figure 1 and 2). Rutile is easy to process to titanium metal or $\mathrm{TiO}_{2}$ pigment by the chlorination method while ilmenite is more complicated because of its high iron content. Since the world reserves of titanium are $90 \%$ in the form of ilmenite and only $10 \%$ in the form of rutile, the treatment of ilmenite is evidently an important question in metallurgy [1,2].

Ilmenite deposits may be massive as in Province of Quebec (Figure 3) or as black sands (Figure 4) associated with magnetite, monazite, and other valuable minerals which are separated by physical methods (Figure 5). In the first magnetic separation a weak magnet is used to separate magnetite while in the second magnetic separation a highintensity magnet is used to separate ilmenite.

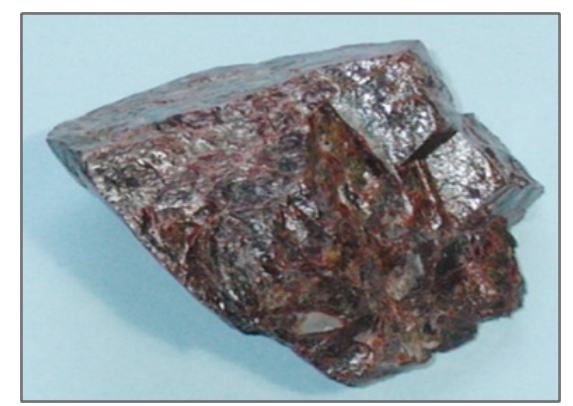

Figure 1. Museum sample of rutile, $\sim 90 \% \mathrm{TiO}_{2}$

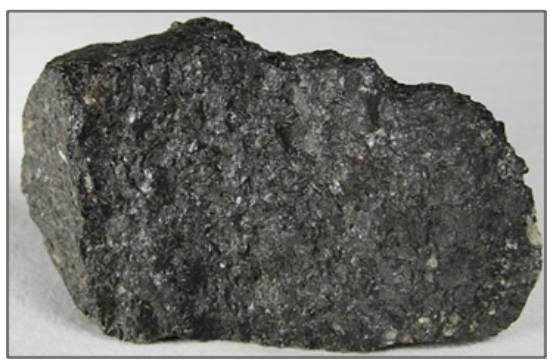

Figure 2. Museum sample of ilmenite, $\mathrm{FeTiO}_{3}\left(59.4 \% \mathrm{TiO}_{2}\right)$.

\section{Early methods for pigment production}

\section{Sulfuric acid method}

In 1916, the Titanium Pigment Corporation of Niagara Falls, New York and the Titan Company of Norway simultaneously began commercial production of this new white pigment. Then, the principal white pigments used in paints were white lead, zinc white, and lithopone. In this method ilmenite was treated with concentrated $\mathrm{H}_{2} \mathrm{SO}_{4}$ at $110-120^{\circ} \mathrm{C}$ to form ferrous and titanyl sulfates:

$$
\mathrm{FeTiO}_{3}+4 \mathrm{H}^{+} \rightarrow \mathrm{Fe}^{2+}+\mathrm{TiO}^{2+}+2 \mathrm{H}_{2} \mathrm{O}
$$

The reaction is conducted in large concrete tanks lined with acid resisting brick (Figure 6), heated by direct injection of high pressure steam or in a pug mill (Figure 7) [3]. The solidified mass produced in the reactor at the end of the reaction was then discharged from the reactor by dissolution in water or dilute acid. After removing the insoluble residue by filtration, the solution containing $120-130 \mathrm{~g} / \mathrm{L}$ $\mathrm{TiO}_{2}$ and $250-300 \mathrm{~g} / \mathrm{L} \mathrm{FeSO}_{4}$ was concentrated under vacuum at $10^{\circ} \mathrm{C}$

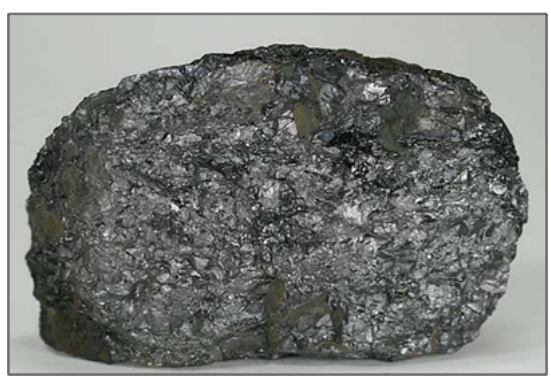

Figure 3. A sample of massive ilmenite of Quebec.

Key words: $\mathrm{HCl}$ leaching, Magpei process, synthetic rutile, oxyhydrolysis, electric furnace, chlorination, sulfuric acid process

Received: August 18, 2016; Accepted: September 22, 2016; Published: September 27, 2016 


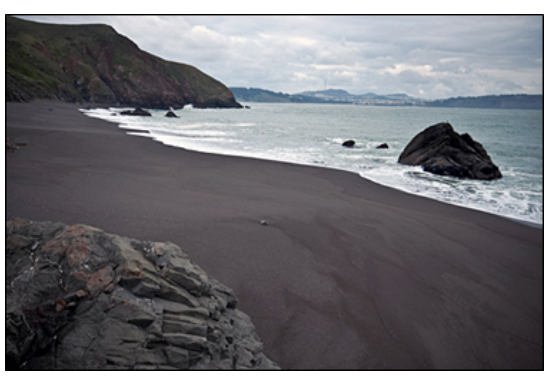

Figure 4. Black beach sands as in India.

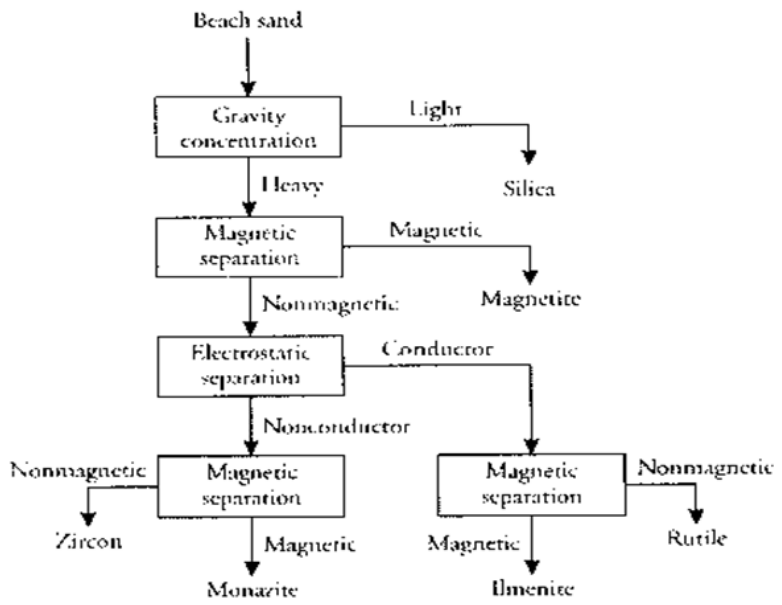

Figure 5. Beneficiation of black sands to recover its valuable components

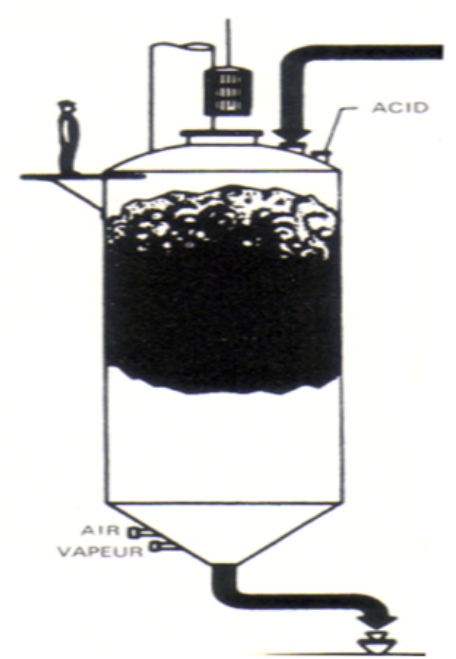

Figure 6. Large concrete tanks lined with acid resisting brick.

to crystallize $\mathrm{FeSO}_{4} \cdot 7 \mathrm{H}_{2} \mathrm{O}$ which was then centrifuged. Titanium oxide is then precipitated from solution by dilution and seeding resulting in the formation of dilute $\mathrm{H}_{2} \mathrm{SO}_{4}$ for disposal (Figures 8 and 9). However, the largest producer of pigment in Salvador, Brazil still uses this technology because it disposes the waste products in the ocean which are removed by the tide.

\section{Chlorination method}

DuPont in USA [4] produces the pigment since 1950 by direct chlorination of ilmenite ore, separation of products by fractional distillation, then oxidation of $\mathrm{TiCl}_{4}$ (Figure 10):

$$
\begin{aligned}
& 2 \mathrm{FeTiO}_{3}+7 \mathrm{Cl}_{2}+3 \mathrm{C} \rightarrow 2 \mathrm{TiCl}_{4}+2 \mathrm{FeCl}_{3}+3 \mathrm{CO}_{2} \\
& \mathrm{TiCl}_{4}+\mathrm{O}_{2} \rightarrow \mathrm{TiO}_{2}+2 \mathrm{Cl}_{2}
\end{aligned}
$$

The problem of this process is recovery of chlorine from ferric chloride or marketing the large amounts of this co-product.

\section{Separation of iron}

Because of the pollution problems associated with the disposal of dilute sulfuric acid and $\mathrm{FeSO}_{4}$, iron in the ore is separated at an early stage. This is achieved in two ways: by electric furnace and by hydrometallurgical routes.

\section{Electric furnace process}

The electric furnace method was developed in 1950s [5]. The ore was mixed with a certain amount of anthracite which was just enough to reduce the iron oxide component of the ore, then charged in an electric furnace at $1650^{\circ} \mathrm{C}$ where iron oxide is reduced to metal while titanium is separated as a slag (Figure 11). The reactions taking place during reduction are the following:

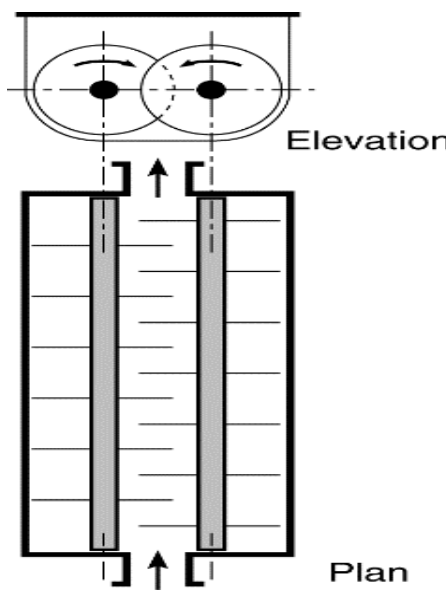

Figure 7. Heated pug mill.

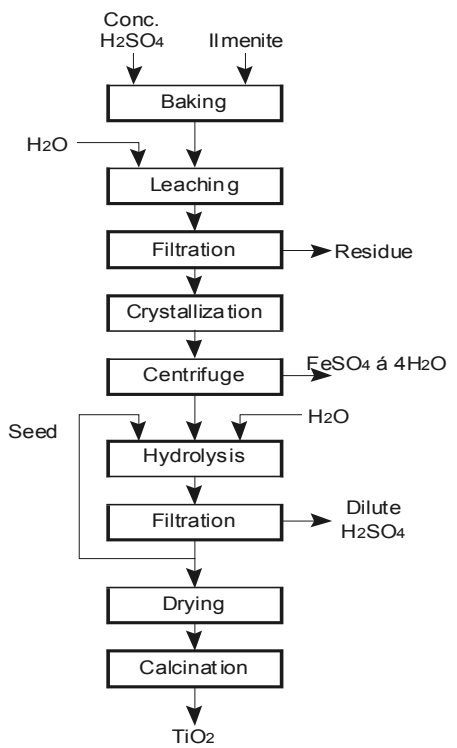

Figure 8. Production of $\mathrm{TiO}_{2}$ pigment by the sulfuric acid process. 


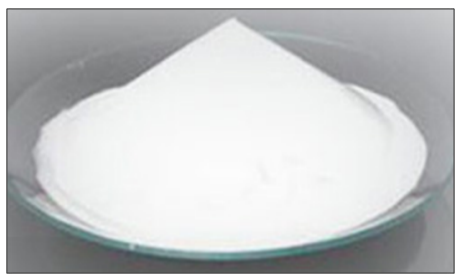

Figure 9. Titanium white, $\sim 100 \% \mathrm{TiO}_{2}$.

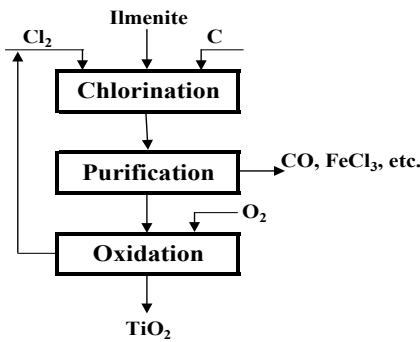

Figure 10. Simplified Du Pont process for pigment production from ilmenite.

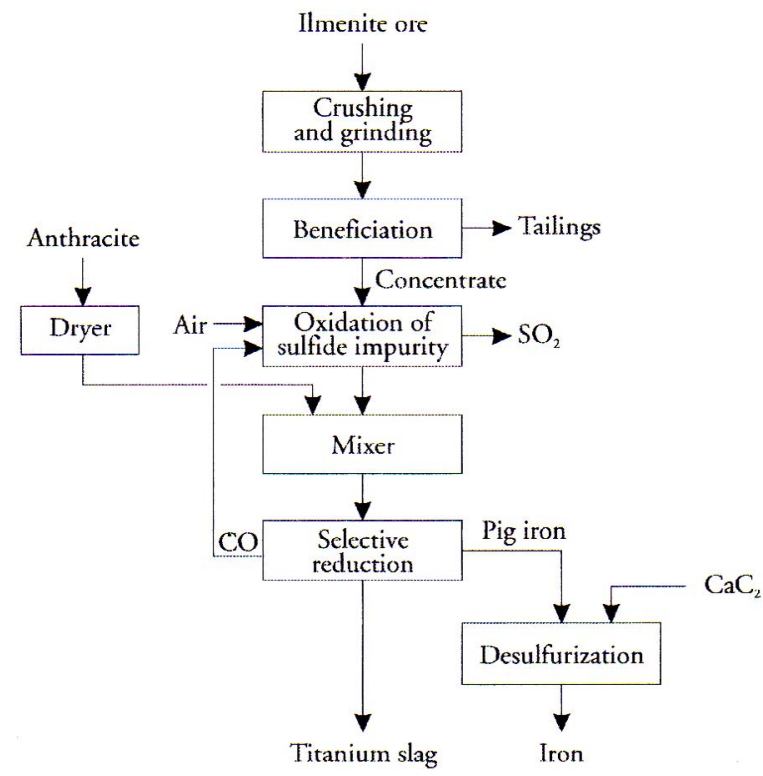

Figure 11. Electric furnace process for iron separation.

$$
\begin{aligned}
& \mathrm{FeTiO}_{3}+\mathrm{C} \rightarrow \mathrm{Fe}+\mathrm{CO}+\mathrm{TiO}_{2 \text { (slag) }} \\
& \mathrm{Fe}_{2} \mathrm{O}_{3}+3 \mathrm{C} \rightarrow 2 \mathrm{Fe}+3 \mathrm{CO}
\end{aligned}
$$

This method is used by the Rio Tinto QIT at its plant in Sorel near Montreal and at Richards Bay in South Africa. It is also used in the Soviet Union at Zaporozhye (Ukraine) and in Japan.

Titanium slag is mainly iron magnesium titanate, $(\mathrm{Fe}, \mathrm{Mg}) \mathrm{Ti}_{4} \mathrm{O}_{10^{2}}$ and a small amount of silicates; typical analyses is $72-85 \%$ total $\mathrm{TiO}_{2}$. A small amount of $\mathrm{TiO}_{2}$ is reduced to $\mathrm{Ti}_{2} \mathrm{O}_{3}$. The reduction of the iron oxides is not taken to completion so that some iron oxide is left in the slag to decrease its melting point. Melting point of $\mathrm{TiO}_{2} 1840^{\circ} \mathrm{C}$ and ilmenite $1435^{\circ} \mathrm{C}$.

The slag is high in titanium and low in iron (Figure 12) and is therefore preferable to ilmenite in manufacturing $\mathrm{TiO}_{2}$ pigment or titanium metal. However, the slag produced in Quebec is not suitable for chlorination because of its high impurity level - about $16.6 \%$ as compared to about $6 \%$ in other slags [6]. These impurities will not only consume unnecessary amounts of chlorine but also will create a disposal problem. Furthermore, some of these impurities, e.g., calcium and magnesium will interfere with the chlorination process itself which is conducted at $800^{\circ} \mathrm{C}$ by forming a molten phase $\left(\mathrm{CaCl}_{2}\right.$ m.p. $770^{\circ} \mathrm{C}$, $\mathrm{MgCl}_{2}$ m.p. $708^{\circ} \mathrm{C}$ ).

For these reasons, titanium slag was used only for making pigment by the sulfuric acid process [7]. The slag was treated in the same way as ilmenite with the exception that no separation of ferrous sulfate was necessary because the bulk of iron was already separated by reduction in the earlier step (Figure 13). The sulfuric acid treatment process of the slag, however, still suffered from the disposal problem of the waste acid and as a result it was abandoned in the 1980s and replaced by a new technology based on upgrading the slag to $94.5 \% \mathrm{TiO}_{2}$ by leaching away most of the impurities by $\mathrm{HCl}$ under pressure to render it suitable for chlorination.

\section{Hydrometallurgical route}

The hydrometallurgical route was developed in 1960s and involved leaching of iron from ilmenite and obtaining a residue rich in titanium $\left(90-95 \% \mathrm{TiO}_{2}\right)$ known as "synthetic rutile" [8]. In one case, the Altair

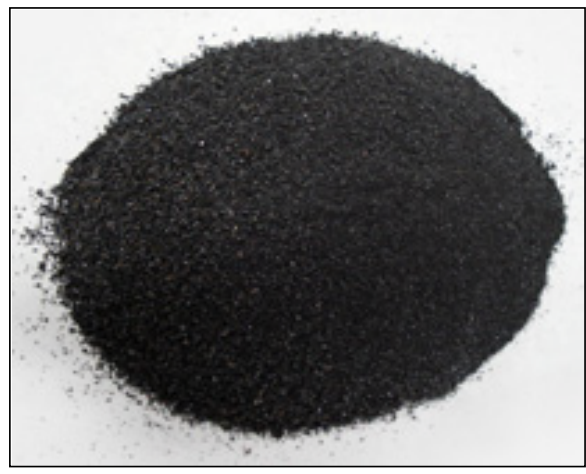

Figure 12. Ground titanium slag, $\mathrm{FeTi}_{4} \mathrm{O}_{10(70-80 \% \mathrm{TiO} 2)}$

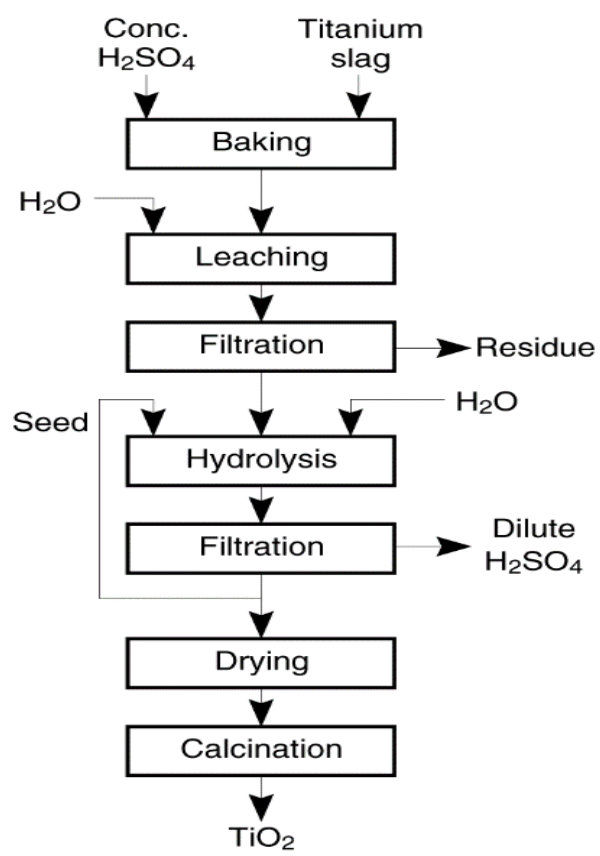

Figure 13. Leaching of titanium slag for production of $\mathrm{TiO}_{2}$ pigment, now obsolete. 
process, a pigment grade $\mathrm{TiO}_{2}$ was obtained. All these processes use an oxyhydrolysis process for treating ferrous chloride to get $\mathrm{HCl}$ for recycle and $\mathrm{Fe}_{2} \mathrm{O}_{3}$ as a by-product.

\section{High-pressure method}

In this method, high grade ilmenite is decomposed in autoclaves by $20 \% \mathrm{HCl}$ at $120^{\circ} \mathrm{C}$ and $200 \mathrm{kPa}$; iron is solubilized as ferrous chloride leaving a solid containing about $95 \% \mathrm{TiO}_{2}$ which has the chemical analysis to rutile that us why it called synthetic rutile (Figure 14):

$$
\mathrm{FeTiO}_{3}+2 \mathrm{H}^{+} \rightarrow \mathrm{TiO}_{2}[\text { impure }]+\mathrm{Fe}^{2+}+\mathrm{H}_{2} \mathrm{O}
$$

Low grade ilmenite cannot be treated by this method since all silicates and insoluble matter will contaminate the product. The synthetic rutile is then treated by chlorine to prepare $\mathrm{TiCl}_{4}$ from which $\mathrm{TiO}_{2}$ or titanium metal are obtained without pollution problems. The process is used in the USA, England, Japan, Taiwan, and Australia. Oxyhydrolysis could be conducted in a variety of ways as described below.

\section{Atmospheric process}

In 2014 it was found by Magpie Incorporation in Canada [9] that low grade ilmenite can be dissolved at $80^{\circ} \mathrm{C}$ with concentrated $\mathrm{HCl}$ at atmospheric pressure. After filtration to remove insoluble matter, the solution is distilled to recover $\mathrm{HCl}$ and to hydrolyse titanyl ion to $\mathrm{TiO}_{2}$. After filtration, the residue is calcined to produce synthetic rutile (Figure 16):

$$
\begin{aligned}
& \mathrm{FeTiO}_{3}+4 \mathrm{HCl} \rightarrow \mathrm{TiO}^{2+}+\mathrm{Fe}^{2+}+4 \mathrm{Cl}^{-}+2 \mathrm{H}_{2} \mathrm{O} \\
& \mathrm{TiO}^{2+}+2 \mathrm{Cl}^{-}+\mathrm{H}_{2} \mathrm{O} \rightarrow \mathrm{TiO}_{2}+2 \mathrm{HCl}
\end{aligned}
$$

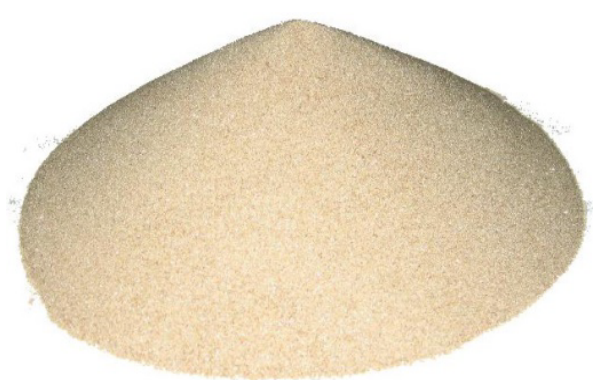

Figure 14. Synthetic rutile $\left(\sim 95 \% \mathrm{TiO}_{2}\right)$.

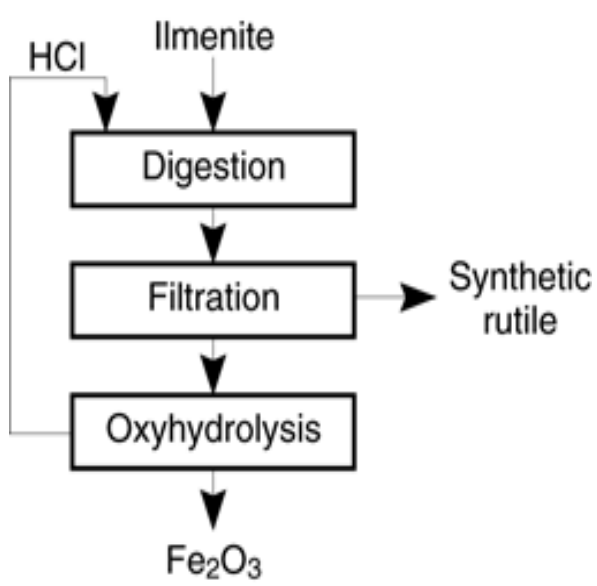

Figure 15. Production of synthetic rutile from ilmenite.
It is evident that the new leaching technology at ambient pressure is superior to the old electric furnace smelting-autoclave upgrading.

\section{Oxyhydrolysis}

Ferrous chloride solution is regenerated to $\mathrm{HCl}$ and $\mathrm{Fe}_{2} \mathrm{O}_{3}$ by oxyhydrolysis:

$$
2 \mathrm{FeCl}_{2}+2 \mathrm{H}_{2} \mathrm{O}+{ }^{1 / 2} \mathrm{O}_{2} \rightarrow \mathrm{Fe}_{2} \mathrm{O}_{3}+\mathrm{HCl}
$$

It is the same technology that is used for treating pickle solution. Two methods are used

\section{Fluidized-bed oxyhydrolysis}

In a fluidized-bed reactor the ferrous chloride solution is introduced onto a large bed of hot ferric oxide where heating is provided by the hot fluidizing combustion gases (Figure 17). As the combustion gas flows through the well agitated bed of oxide it quickly reaches thermal equilibrium with the bed. The solution is fed on top of the bed of oxides. The liquid feed wets the outer layer of the hot oxide particles and is quickly evaporated to form an onion-like layer of new solid oxide on top of the existing oxide, thereby producing dense homogeneous particles.

\section{Spray roaster oxyhydrolysis}

In this type of oxyhydrolysis roaster, the ferrous chloride solution is sprayed into an empty cylindrical vessel, while the required energy

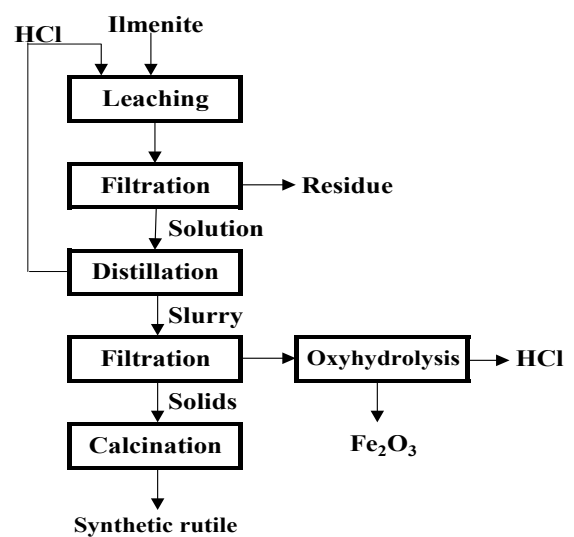

Figure 16. Production of $98+\% \mathrm{TiO}_{2}$ from a low-grade ilmenite [Magpie process].

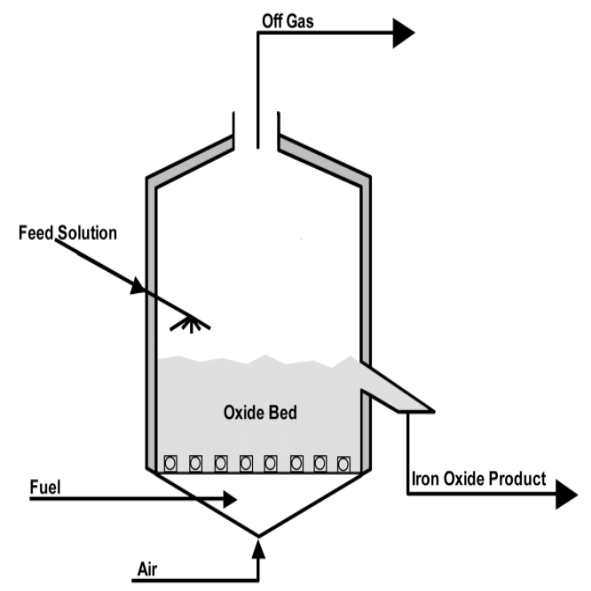

Figure 17. Fluidized-bed reactor for oxyhydrolysis of ferrous chloride 
is supplied by the up flow of hot gases generated in the bottom burners (Figure 18). Spray roasters have large diameters to keep the gas velocities low. If the gas velocity is high, too many particles are elutriated with the off-gas, and the product quality and the efficiency of the roaster drop. The off-gas and oxides leave the roaster countercurrently at about $400^{\circ} \mathrm{C}$ to $500^{\circ} \mathrm{C}$. The residence time of the sprayed particles in the high-temperature reaction zone is very short; therefore, very small liquid droplets, which can be quickly heated, should be created by atomization. The fast heat-up results in the formation of a solid oxide crust on the surface of each droplet. As the bulk of the droplet heats, the water content vaporizes and breaks through the oxide shell. Therefore, the spray roasted oxide is composed of very fine "fluffy," hollow spheres.

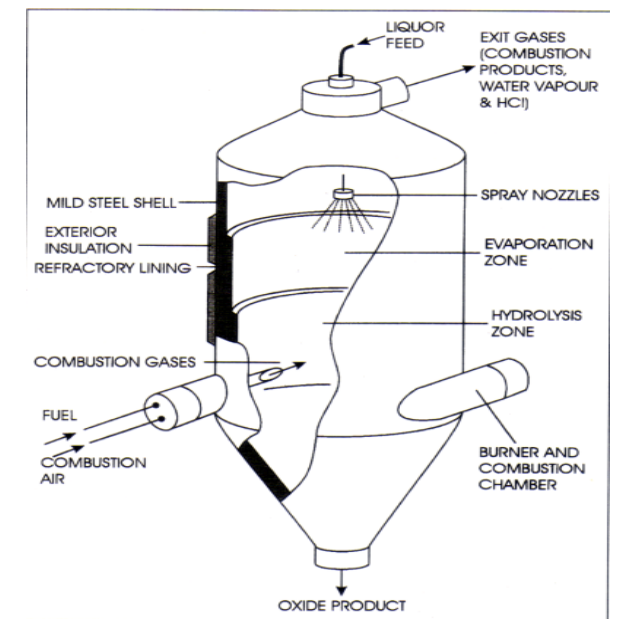

Figure 18. Regeneration of $\mathrm{HCl}$ from ferrous chloride solution by oxyhydrolysis in spray roaster.

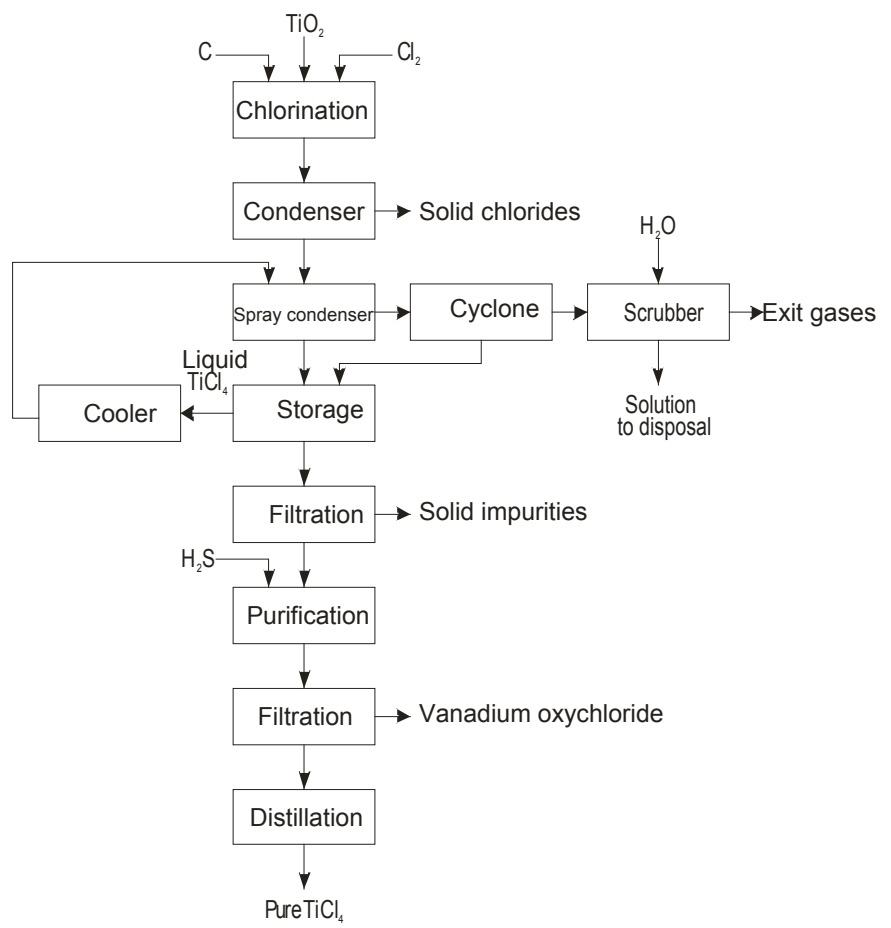

Figure 19. Production of $\mathrm{TiCl}_{4}$ from rutile, synthetic rutile, or titanium slag.

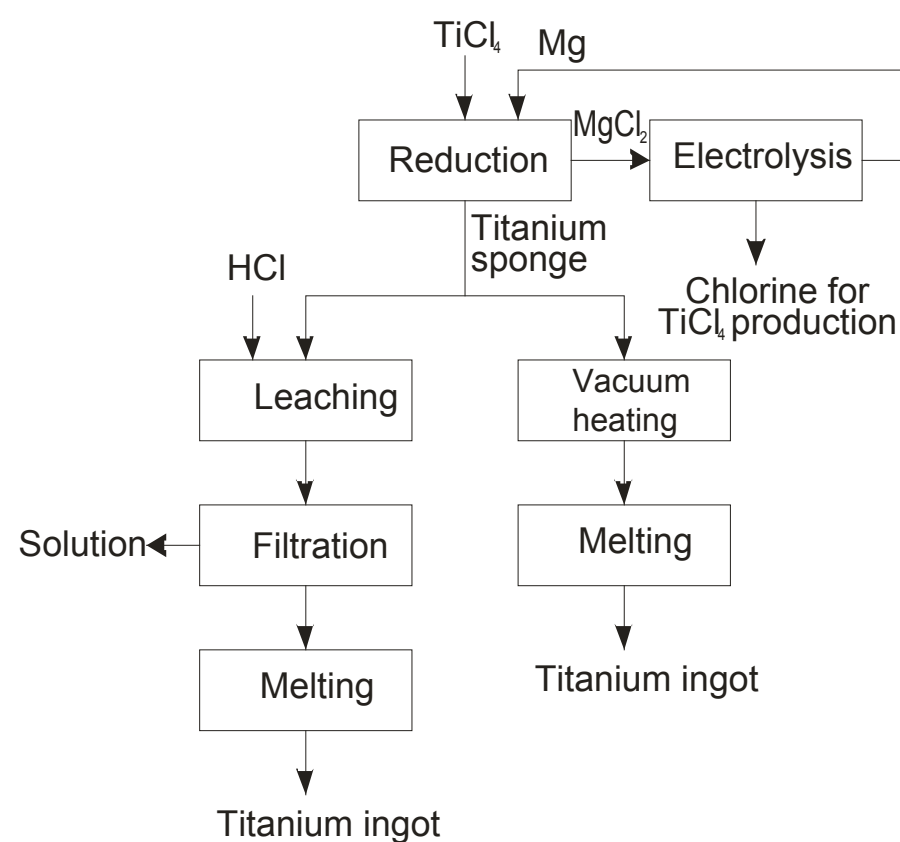

Figure 20. Production of titanium from $\mathrm{TiCl}_{4}$.

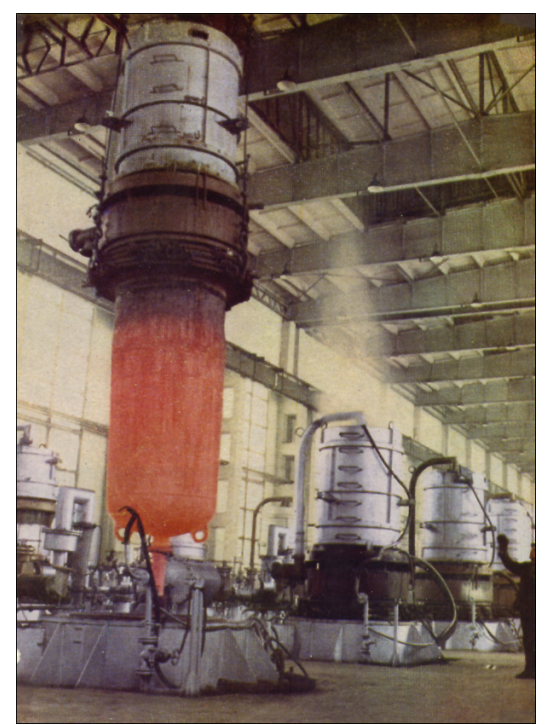

Figure 21. Metallothermic reactor being removed from furnace.

\section{Production of titanium}

Metallic titanium is produced by chlorination of rutile, synthetic rutile, or titanium slag then reduction in a metallothermic reactor of $\mathrm{TiCl}_{4}$ by magnesium to titanium (Figures 19 and 20) [10]:

$$
\begin{aligned}
& \mathrm{TiO}_{2}+\mathrm{C}+2 \mathrm{Cl}_{2} \rightarrow \mathrm{TiCl}_{4}+\mathrm{CO}_{2} \\
& \mathrm{TiCl}_{4}+\mathrm{Mg} \rightarrow \mathrm{Ti}+\mathrm{MgCl}_{2}
\end{aligned}
$$

Magnesium chloride is then electrolyzed to get back the magnesium and chlorine for recycle. Figure 21 shows the metallothermic reactor removed from the furnace after reduction from which titanium sponge is recovered (Figure 22). 


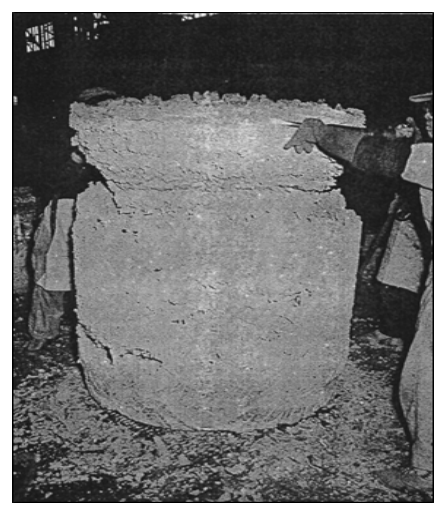

Figure 22. Titanium sponge (top) and $\mathrm{MgCl}_{2}$ (bottom) removed from the reactor.

\section{References}

1. Barksdale J (1966) Titanium, Its Occurrence, Chemistry and Technology, Ronald Press, New York.

2. Sibum H (1997) "Titanium”, pp. 1129-1179 in Handbook of Extractive Metallurgy edited by F. Habashi, published by WILEY-VCH, Weinheim, Germany.

3. Habashi F (1993) A Textbook of Hydrometallurgy ( $2^{\text {nd }}$ edtn). Métallurgie Extractive Québec, Québec City, Canada.

4. DuPont (2007) Brochure ${ }^{\mathrm{TM}}$ Ti-Pure ${ }^{\circledR}$ titanium dioxide.

5. Habashi F (2002) Textbook of Pyrometallurgy, Métallurgie Extractive Québec, Québec City, Canada.

6. Toromanoff I, Habashi F (1985) Transformation of a Low-Grade Titanium Slag into Synthetic Rutile Intern. J. Mineral Processing 15: 65-81.

7. Habashi F (1996) Pollution Problems in the Mineral and Metallurgical Industries, Metallurgy Extractive Quebec, Quebec City.

8. Habashi F (1993) Pressure Hydrometallurgy (2ndedtn). Métallurgie Extractive Québec, Québec City, Canada.

9. Habashi F, Kamaleddine F, Bourricaudy E (2015) A New Process to Upgrade Ilmenite to Synthetic Rutile Proceedings Conference of Metallurgists, Canadian Institute of Mining, Metallurgy, and Petroleum, Montreal. Reprinted in Metall 69: 27-30.

10. Habashi F (1993) Two Hundred Years Titanium. The Processing of Titanium Ores for Pigment and Metal Production. Arab Min J 11: 74-84.

Copyright: $\mathbb{C} 2016$ Habashi F. This is an open-access article distributed under the terms of the Creative Commons Attribution License, which permits unrestricted use, distribution, and reproduction in any medium, provided the original author and source are credited. 